Maurice A. Deane School of Law at Hofstra University Scholarly Commons at Hofstra Law

Hofstra Law Faculty Scholarship

1985

\title{
Cleaning Up in Bankruptcy: Curbing Abuse of the Federal Bankruptcy Code by Industrial Polluters
}

Norman I. Silber

Maurice A. Deane School of Law at Hofstra University

Follow this and additional works at: https://scholarlycommons.law.hofstra.edu/faculty_scholarship

\section{Recommended Citation}

Norman I. Silber, Cleaning Up in Bankruptcy: Curbing Abuse of the Federal Bankruptcy Code by Industrial Polluters, 85 Colum. L. Rev. 870 (1985)

Available at: https://scholarlycommons.law.hofstra.edu/faculty_scholarship/750

This Article is brought to you for free and open access by Scholarly Commons at Hofstra Law. It has been accepted for inclusion in Hofstra Law Faculty Scholarship by an authorized administrator of Scholarly Commons at Hofstra Law. For more information, please contact lawcls@hofstra.edu. 


\section{CLEANING UP IN BANKRUPTCY: CURBING ABUSE OF THE FEDERAL BANKRUPTCY CODE BY INDUSTRIAL POLLUTERS}

An increasing number of industrial polluters have taken advantage of protective features of the Federal Bankruptcy Code ${ }^{1}$ to avoid compliance with environmental injunctions, and thus have undermined the enforcement of environmental laws designed to protect the public from toxic wastes. Two provisions of the Code are at issue: section $362,{ }^{2}$ which stays judicial proceedings against a party that files a bankruptcy petition; and section $554,{ }^{3}$ which allows a trustee to abandon burdensome property. The lower courts have struggled, with little success, to find allowable limits to the protection afforded by these statutory provisions. Both provisions have come to the attention of the Supreme Court. Recently, in Ohio v. Kovacs, ${ }^{4}$ the Supreme Court considered whether an environmental injunction that had been stayed through the automatic stay could be discharged in bankruptcy. In the coming term, the Supreme Court will review In $r e$ Quanta Resources Corp.,,$^{5}$ which involves the propriety of qualifying the privilege of abandonment to protect the public interest.

This Note examines the issues raised by these cases, and proposes a legislative solution to the problems encountered when industrial polluters go into bankruptcy. Part I examines case law concerned with sections 362 and 554, and proceeds to analyze the Kovacs decision. Part II confronts the issues surrounding section 554 as they have been raised in the Quanta case.

Argning that Kovacs did not resolve problems related to section 362 , and that the disallowance of abandonment would be inconsistent with the language and purpose of section 554, the Note concludes that congressional amendment of the bankruptcy law is necessary. Part III therefore proposes an interrelated set of changes to sections 554(a), ${ }^{6}$ $523(\mathrm{a}),{ }^{7}$ and $507^{8}$ of the Code in order to close loopholes, deter irre-

1. Bankruptcy Reform Act of 1978, Pub. L. No. 95-598, 92 Stat. 2549 (codified at 11 U.S.C. $\S \S 101-151,326$ (1982) and scattered sections of 28 U.S.C.).

2. 11 U.S.C. $\S 362$ (1982).

3. Id. $\S 554$ (a).

4. 105 S. Ct. 705 (1985) (Kovacs $I I$ ), aff'g, Ohio v. Kovacs, 717 F.2d 984 (6th Cir. 1983).

5. 739 F.2d 912 (3d Cir. 1984), cert. granted sub nom. O'Neill v. New York, 53 U.S.L.W. 3597 (U.S. Feb. 19, 1985) (No. 84-805) and case consolidated with In re Quanta Resources Corp., 739 F.2d 927 (3d Cir. 1984), cert. granted sub nom. Midlantic Nat'l Bank v. New Jersey Dep't of Envtl. Protection, 53 U.S.L.W. 3597 (U.S. Feb. 19, 1985) (No. 84-801).

6. 11 U.S.C. $\$ 554(\mathrm{a})$ (1982).

7. Id. $\S 523(a)$.

8. Id. § 507. 
sponsible waste disposal, and improve the chance that debts owed by individual polluters will be repaid.

\section{The Bankruptcy Code and Hazardous Waste Gleanup}

\section{A. The Resort to Bankmuptcy by Industrial Polluters}

Hazardous waste disposal has emerged as a truly nationwide concern. A report prepared for Congress points to as many as 50,000 toxic waste sites in the United States, each posing severe public health risks, and each with cleanup costs ranging from thousands of dollars to several million. ${ }^{9}$ Since 1979 , the federal government and at least thirty-six states have responded with legislation.10 The result is a "complex and diverse new body of state law,"11 imposing tighter standards than ever before on businesses that handle toxic substances. ${ }^{12}$

The need to comply with environmental regulations and to pay escalating liability insurance rates has boosted operating costs for businesses that own potentially hazardous waste sites. ${ }^{13}$ Unable to absorb the cost of environmental regulations, some companies have gone into voluntary bankruptcy to seek protection from their creditors. ${ }^{14}$ Under the Bankruptcy Code, companies unable to comply with state or federal cleanup orders have two options. Chapter 11 of the Code allows a debtor to continue in business under a court-approved reorganization

9. Senate Comm. on Envtl. and Pub. Works, Injuries and Damages from Hazardous Wastes-Analysis and Improvement of Legal Remedies, A Report to Congress in Compliance with Section 301 (e) of the Comprehensive Environmental Response, Compensation, and Liability Act of 1980 by the "Superfund Section 30I(3) Study Group," S. Comm. Serial No. 12, 97th Cong., 2d Sess. 21 (I982). A recent internal report prepared for the Environmental Protection Agency has estimated that the Federal Government will have to spend between $\$ 8.4$ and $\$ 16$ billion to clean up between 1400 and 2200 of the sites. See N.Y. Times, Feb. 8, 1984, at A18, col. 1.

10. See Warren, State Hazardous Waste Superfunds and CERCLA: Conflict or Complement?, 13 Envtl. L. Rep. (Envtl. L. Inst.) 10,348 (1983) (listing state superfund laws).

11. Id.

12. Id. at $10,352,10,358-60$.

13. According to James Gutensohn, the Commissioner of the Massachusetts Department of Environmental Management, new rnles have pushed storage costs for hazardous chemical waste from about $\$ 24$ per barrel in the late 1970 s to more than $\$ 100$ per barrel in 1984. Marcus, The Recycling of Chemical Waste, N.Y. Times, Jan. 8, 1984, $\S 3$, at 4 , col. 3 .

14. As Richard Engel, Deputy Attorney General for the State of New Jersey, has said, the federal bankruptcy laws have "increasingly become a bar to the enforcement of environmental laws" in that state. In approximately 10 major cases per year, defendants in New Jersey seek shelter from environmental enforcement through bankruptcy. Telephone interview with Richard Engel, Assistant Attorney General, Office of the Attorney General of New Jersey (Feb. 8, 1985); see also Hoffman, Environmental Protection and Bankruptcy Rehabilitation: Toward a Better Compromise, II Ecology L.Q. 671, 676-79 (1984) (discussing the ability of solvent debtors to take advantage of the Bankruptcy Code); Rosenbaum, Bankruptcy and Environmental Regulation: An Emerging Conflict, 13 Envtl. L. Rep. (Envtl. L. Inst.) 10,099, 10,103 (1983). 
plan. ${ }^{15}$ When reorganization under chapter 11 is unworkable because cleanup would drain capital needed to continue operations, ${ }^{16}$ the company may invoke chapter 7 liquidation proceedings to distribute assets of the estate in an orderly manner to the creditors. ${ }^{17}$ Under either chapter, the federal bankruptcy law may offer two shelters from the high cost of complying with cleanup orders: the trustee may invoke the protection of the automatic stay provision, 11 U.S.C. \& 362, or petition for court approval to abandon the property under 11 U.S.C. $\$ 554$.

The automatic stay provision suspends the "commencement or continuation" of all "judicial, administrative, or other . . . proceeding[s] against the debtor" upon the filing of a bankruptcy petition. ${ }^{18}$ Among other things, section 362(a) therefore precludes an environmental protection agency from suing a bankrupt polluter to recover any expenses incurred in detoxifying a waste site. ${ }^{19}$ The abandonment provision, 11 U.S.C. $\$ 554(\mathrm{a})$, permits a trustee, with court approval, to abandon any property found to be "burdensome" or of "inconsequential value" to an estate. ${ }^{20}$ Upon the abandonment of any property by the trustee, title to it reverts to the debtor, who is judgment-proof, and the estate is relieved of the obligation to detoxify the site. ${ }^{21}$ These two provisions of the bankruptcy code offer hazardous waste site handlers shelter from rigorous environmental requirements.

The inducement to disregard rising standards and costs of waste disposal becomes stronger because of the knowledge that, if necessary, bankruptcy provisions will provide a protective shield. ${ }^{22}$ Since bankrupt polluters can avoid environmental enforcement efforts under the

15. 11 U.S.C. $\$ \S 1101-1129$ (1982).

16. See infra text accompanying notes $126-28$.

17. 11 U.S.C. $\S \S 701-728$ (1982).

18. Id. § 362(a) (1982). The section in pertinent part provides:

Except as provided in subsection (b) of this section, a petition filed under . . . this title ... operates as a stay, applicable to all entities, of-(1) the commencement or continuation . . . of a judicial, administrative, or other action or proceeding against the debtor that was or could have been commenced before the commencement of the case under this title, or to recover a claim against the debtor that arose before the commencement of the case under this title; (2) the enforcement, against the debtor or against property of the estate, of a judg. ment obtained before the commencement of the case under this title; (3) any act to obtain possession of property of the estate ....

19. This section may also prevent environmental authorities from enforcing cleanup orders. See infra notes 28-34 and accompanying text.

20. 11 U.S.C. \& 554(a) (1982). This section provides for abandonment after notice and a hearing. A debtor in possession has nearly all the rights of a trustee, including the right to abandon property. See 11 U.S.C. \& 1107(a) (1982).

21. 4 Collier on Bankruptcy, I 554.02 (15th ed. 1984); see also Mason v. Commissioner, 646 F.2d 1309, 1310 (9th Cir. 1980) (" $[W]$ hen the court grants a trustee's petition to abandon property . . . any title rested in the trustee is extinguished, and the title reverts to the bankrupt. . ...").

22. See infra text accompanying notes $35-43$; see also Hoffman, supra note 14 , at 676-79 (potential for abuse created by the stay provision and definition of insolvency in 
stay or the abandonment provisions, state and federal environmental authorities are often forced to use their own funds to restore hazardous waste sites. When they do use their funds and thereby accrue cleanup debts, furthermore, debt recovery is highly unlikely, since as unsecured creditors, governmental units occupy a low priority under the existing Bankruptcy Code. It was clearly not the intent of Congress that the federal bankruptcy proceeding should shield irresponsible polluters from environmental injunctions or shift cleanup costs onto taxpayers. The courts, however, have not succeeded in defining an appropriate solution for curbing bankruptcy abuse. ${ }^{23}$

\section{B. The Case Law}

Application of section 362(a), the automatic stay provision, to government suits to enforce cleanup orders has generated much controversy. ${ }^{24}$ The provision is subject to explicit exceptions for governmental actions to enforce police or regulatory power, ${ }^{25}$ or to enforce a nonmonetary judgment in such an action or proceeding. ${ }^{26}$ Although the provision's legislative history plainly indicates that Congress considered a state's enforcement of an environmental order an exercise of its "police or regulatory power,"27 courts have been unable to agree whether a cleanup order is essentially equivalent to a money judgment and is therefore outside the scope of the "nonmonetary judgment" exception, or whether, as a governmental injunction, it is not stayed by the filing of a bankruptcy petition.

In United States v. Johns-Manville Sales Corp.,${ }^{28}$ for instance, a district court in New Hampshire vacated an order by the Environmental Pro-

the Code); Rosenbaum, supra note 14, at 10,103 (discussion of actions of JohnsManville corporation).

23. For further discussion of the nature of bankruptcy abuse, see infra text accompanying notes $101-61$.

24. See infra text accompanying notes 28-34.

25. 11 U.S.C. $\$ 362(\mathrm{~b})(4)$ (1982).

26. Id. $\S 362(\mathrm{~b})(5)$. The policy of restricting the exception to nonmonetary judgments is to avoid unfairness to other creditors. As the relevant Senate report explains, "[s]ince the assets of the debtor . . . constitute a fund out of which all creditors are entitled to share, enforcement by a governmental unit of a money judgment would give it preferential treatment to the detriment of all other creditors." S. Rep. No. 989, 95th Cong., 2d Sess. 52, reprinted in 1978 U.S. Code Cong. \& Ad. News 5787, 5838; see also H.R. Rep. No. 595, 95th Cong., 2d Sess. 343, reprinted in 1978 U.S. Code Cong. \& Ad. News 5963, 6299 (identical to S. Rep.).

27. The Senate Report states that where a government unit is suing a debtor "to prevent or stop violation of fraud, environmental protection, consumer protection, safety, or similar police or regulatory laws, or attempting to fix damages for violation of such a law," or affecting the "enforcement of an injunction," the action should not be stayed under the automatic stay. S. Rep. No. 989, 95th Cong., 2d Sess. 52 (emphasis added), reprinted in 1978 U.S. Code Cong. \& Ad. News 5787, 5838; see also H. Rep. No. 595, 95th Cong., 2d Sess. 343, reprinted in 1978 U.S. Code Cong. \& Ad. News 5963, 6299 (identical to S. Rep.).

28. 13 Envtl. L. Rep. (Envtl. L. Inst.) 20,310 (D.N.H. 1982). 
tection Agency (EPA) requiring Johns-Manville to remove asbestos contamination from a waste site. The court held that the order in effect required "the expenditure of substantial funds from the assets of Manville," 29 and was therefore equivalent to a money judgment subject to the automatic stay. In another case, In re Kovacs (Kovacs $I$ ), ${ }^{30}$ the Sixth Circuit decided that because a debtor could only clean up the toxic waste he had released by spending money, the state's suit to enforce the environmental injunction fell within the scope of section 362(a) and was stayed by the bankruptcy proceedings. ${ }^{31}$ By contrast, the Third Circuit upheld a consent order requiring the owner of a hazardous mine to backfill land, seal off a mine opening, remove contaminated topsoil, and submit comprehensive plans for further action. ${ }^{32}$ The court held that the consent order was within the "nonmonetary judgment" exception, even though compliance would deplete the estate. ${ }^{33}$ Similarly, a district court in Puerto Rico refused to stay an order requiring a chapter 1 I trustee to conform with air quality regulations, notwithstanding the fact that to comply, the estate would have to spend $\$ 323,000$ for dust control equipment. ${ }^{34}$

The abandonment provision, section 554, has also been the subject of dispute. In In re Quanta Resources, ${ }^{35}$ a waste processing corporation was threatened with a $\$ 2.5$ million cleanup bill pressed by the New York Department of Environmental Protection ${ }^{36}$ and a costly environmental injunction from the New Jersey Department of Environmental Protection. ${ }^{37}$ Arguing that compliance would deplete the estate, Quanta Resources attempted in bankruptcy to abandon two waste sites contaminated with polychlorinated biphenyls (PCBs). Since section 554 on its face gave the trustee a right to abandon all burdensome assets, the bankruptcy court granted the petition. ${ }^{38}$ Reversing both the

29. Id. at $20,3 \mathrm{II}$.

30. 681 F.2d 454 (6th Cir. 1982), vacated, 459 U.S. 1167 (1983).

31. Id. See infra notes $48-50$ and accompanying text. 1984).

32. Penn Terra Ltd. v. Department of Envtl. Resources, 733 F.2d 267 (3d Cir.

33. Penn Terra Ltd. operated coal surface mines in western Pennsylvania. The Department of Environmental Resources found the corporation guilty of failing to maintain adequate erosion and sedimentation controls, failing to treat mine drainage properly, and other violations. 733 F.2d at 269-70 nn.2-3 (3d Cir. 1984).

34. In re Canarico Quarries, Inc., 466 F. Supp. 1333, 1334 (D.P.R. 1979).

35. 739 F.2d 912 (3d Cir. 1984), cert. granted sub nom. O'Neill v. New York, 53 U.S.L.W. 3597 (U.S. Feb. 19, 1985) (No. 84-805) and case consolidated with in re Quanta Resources Corp., 739 F.2d 927 (3d Cir. 1984), cert. granted sub nom. Midlantic Nat'l Bank v. New Jersey Dep't of Envtl. Protection, 53 U.S.L.W. 3597 (U.S. Feb. 19, 1985) (No. 84-801).

36. 739 F.2d at 914 .

37. $739 \mathrm{~F} .2 \mathrm{~d}$ at 928 .

38. An abandonment order was issued for each site. In re Quanta Resources, No. 81-05967 (Bankr. D.N.J., filed July 7, 1982 (N.Y. site); May 20, 1983 (N.J. site)). 
bankruptcy court and the district court, ${ }^{39}$ the Third Circuit subjected section 554(a) to a balancing test and, to promote the public interest, prohibited the trustee from abandoning the sites. ${ }^{40}$ Other courts have followed this analysis of section 554(a). ${ }^{41}$

The confusion in the case law reflects the failure by courts to reconcile the competing policies underlying the Bankruptcy Code and environmental enforcement statutes with any consistency. A recent decision by a Massachusetts bankruptcy court illustrates the magnitude of the problem. In In re Charles George Land Reclamation Trust, ${ }^{42}$ fearing that a corporation would take shelter behind the automatic stay and abandonment provisions and shed its cleanup obligations altogether, the court simply dismissed the bankruptcy petition filed by the owner of the waste site. ${ }^{43}$ Such a severe measure is hardly consistent with the congressional purpose in enacting a comprehensive and uniform national bankruptcy statute. ${ }^{44}$

Early in 1985, in Ohio v. Kovacs (Kovacs II), ${ }^{45}$ the Supreme Court addressed the conflict between environmental laws and the Bankruptcy Code for the first time. Kovacs II does not, however, provide lower courts with much guidance.

\section{Environmental Consent Orders and Money Judgments: Ohio v. Kovacs}

Ohio v. Kovacs considered the question of whether a debtor's obligation under an environmental consent order constitutes a "debt" 46 dischargeable under section 727 (b) in a personal bankruptcy proceeding. ${ }^{47}$ In a narrow ruling, the Supreme Court decided that environmental consent orders which have been reduced to simple requests for money through the appointment of a receiver are equivalent to requests for money judgments, and therefore are dischargeable.

Kovacs had a complicated history. The case was originally brought by Ohio against Chem-Dyne Corporation and Kovacs, its president and

39. The District Court affirmed the New York order. In re Quanta Resources, No. 82-3524 (D.N.J., Jan. 25, 1983) (N.Y. site).

40. 739 F.2d at 929 .

41. An Ohio bankruptcy court held that $\$ 554$ (a) contains an implicit public policy exception, and prevented a bankrupt chemical company from abandoning buried drums of hazardous material. In re T.P. Long, 45 Bankr. 278 (Bankr. N.D. Ohio 1985). The cleanup costs incurred by the EPA therefore became obligations of the estate.

42. 30 Bankr. 918 (Bankr. D. Mass. 1983).

43. Id. at 924-25.

44. The Bankruptcy Code directs that, in dismissing or suspending a bankruptcy proceeding, the best interests of the creditors and the debtor should thereby be served. 11 U.S.C. $\$ 305$ (1982).

45. 105 S. Ct. 705 (1985).

46. 11 U.S.C. $\$ 101(11)(1982)$.

47. Id. $\$ 727$ (b) (1982). Under $\S 727$ (b) a discharge relieves the debtor of all debts which arose prior to the order for relief, except for those debts which are nondischargeable under $\S 523(\mathrm{a})$, see infra text accompanying notes 129-33. Only parties other than corporations may be discharged, see 11 U.S.C. § 727(a)(1) (1982). 
chief executive officer, for polluting public waters, maintaining a nuisance, and killing wildlife, all in violation of state environmental laws. Kovacs failed to comply with a stipulation which enjoined him from causing further pollution and which ordered him to pay $\$ 75,000$ to compensate for injury to wildlife. When the state appointed a receiver to take possession of all assets belonging to Kovacs and his company, Kovacs filed a personal bankruptcy petition, and asked the bankruptcy court to stay all further efforts to collect the $\$ 75,000$ owed under the stipulation. 48

The Sixth Circuit held that the receiver's effort to seize Kovacs' assets to satisfy the $\$ 75,000$ judgment was a demand for a money payment that could be stayed under section 362(a). ${ }^{49}$ While Ohio's appeal to the Supreme Court for a lifting of the stay was pending, the state moved in the bankruptcy proceeding for a declaratory judgment that the cleanup obligation was not a "debt" dischargeable under section 727(b). 50 The Supreme Court vacated the Sixth Circuit's ruling on the automatic stay in Kovacs $I,{ }^{51}$ and it affirmed the dischargeability of the stipulated obligation in Kovacs II. ${ }^{52}$ The Court, however, carefully confined its holding in Kovacs II to situations where the defendant cannot render performance " 'other than by the payment of money.' "53 That the state had secured a receiver to take possession of Kovacs' assets was significant, the Court stated, since it was clear that the receiver wanted from Kovacs only money to defray cleanup costs. Ohio therefore had converted the cleanup order "into an obligation to pay money, an obligation that was dischargeable in bankruptcy." 54

By stressing the significance of the appointment of a receiver, however, the Court left open the question whether other types of enforcement orders might be classified as nonmonetary obligations. ${ }^{55}$ For example, an environmental order may require that a polluter retain an expert consultant to perform expensive testing and decontamination procedures, or maintain supervision over contaminated property until it is no longer hazardous. ${ }^{56}$ Such requirements could not be performed

48. In re Kovacs (Kovacs $I$ ), 681 F.2d 454, 454-55 (6th Cir. 1982).

49. Id. at 456 .

50. The bankruptcy court and district court denied the state's motion. The Sixth Circuit affirmed. Ohio v. Kovacs (Kovacs II), 717 F.2d 984 (6th Cir. 1983).

51. 459 U.S. 1167 (1983). The Sixth Circuit's ruling, which subjected Ohio's action to the stay provision in Kovacs $I$, thus was not reviewed by the Supreme Court. Both Kovacs $I$ and Kovacs $I I$ addressed the money judgment issue; but dischargeability, not the stay provision, was directly at issue in Kovacs II.

52. 105 S. Ct. 705 (1985). 1982)).

53. 105 S. Ct. at 709 (quoting In re Kovacs, 29 Bankr. 816, 816 (Bankr. S.D. Ohio

54. Id. at 711 (footnote omitted).

55. See generally Annot., 58 A.L.R. Fed. 282 (1982) (discussing cases that consider whether to invoke exceptions to the stay).

56. See EPA Memorandum Outlining Guidelines for Enforcing Federal District Court Orders, Negotiated Consent Decrees, 14 Env't Rep. (BNA) 2353 (Apr. 27, 1984) 
by the debtor personally, and arguably in their essentials would be requests for money. The Court, however, specifically disclaimed any intent to hold that all environmental injunctions are "debts" dischargeable in personal bankruptcy. Indeed, in dictum, the Court distinguished Kovacs II from the Third Circuit's holding in Penn Terra Ltd. v. Department of Environmental Resources ${ }^{57}$ that an injunction to backfill a mine fell within the nonmonetary judgment exception to the automatic stay provision. ${ }^{58}$ Expressing approval of Penn Terra, the Court explained that "[t]he automatic stay provision does not apply to suits to enforce the regulatory statutes of the State, but the enforcement of such a judgment by seeking money from the bankrupt . . . is another matter."59

In avoiding the crucial question of whether an environmental injunction that a debtor can comply with only by the payment of money falls within section 362(a), Kovacs II not only failed to clarify the competing concerns of the Bankruptcy Code and environmental statutes; it also created uncertainty for trustees or debtors in possession, for creditors, and for state environmental authorities. ${ }^{60}$ Despite Justice O'Connor's comment that the decision "cannot be viewed as hostile to state enforcement of environmental laws,"61 state and federal officials have expressed fear that the case may encourage polluters to exploit the Bankruptcy Code and thus have a wider impact than the Court intended. ${ }^{62}$ It may, for example, affect the use of the abandonment provision, since the chance that a cleanup order may be enforced notwithstanding the automatic stay will lead practitioners, where possible, to look to 554(a) for a more certain way to avoid cleanup costs. When the Supreme Court reviews In re Quanta Resources this term, it will consider whether or not abandonment can always be used to shed burdensome property.

(calling for specification of particular mechanisms and schedules, and for explicit compliance verification requirements).

57. Penn Terra Ltd. v. Department of Envtl. Resources, 733 F.2d 267 (3d Cir. 1984); see supra notes $32-33$ and accompanying text.

58. 105 S. Ct. at 711 n.11.

59. $1 \mathrm{~d}$.

60. Telephone interview with Robert Salzman, counsel to New York State Assembly, Environmental Conservation Committee (Jan. 28, 1985) (signals sent to polluters indicate the availability of discharge to avoid cleanup debts); telephone interview with Michael Crames, of the firm Levin, Weintraub \& Crames (Jan. 25, 1985) (vulnerability of the automatic stay to injunctions); telephone interview with Richard Nagel, Assistant Attorney General, Office of the Attorney General of New Jersey (Feb. 8, 1985) (possible exploitation of other provisions of the Code in the wake of Kovacs II); see also Baird \& Jackson, Kovacs and Toxic Wastes in Bankruptcy, 36 Stan. L. Rev. 1199 (1984) (anticipating confusion about a limited decision in Kovacs II by the Supreme Court).

61. Ohio v. Kovacs, 105 S. Ct. 705, 712 (1985) (O'Connor, J., concurring).

62. Wall St. J., Jan. 10, 1985, at 14, col. 3. 


\section{The Abandonment Provision: In Re Quanta Resources CorP.}

Until recently, most of the conflicts between government environmental objectives and the Bankruptcy Code have centered on the automatic stay provision. In re Quanta Resources was the first case to address the impact of the abandonment provision, section 554, on environmental enforcement.

\section{A. In re Quanta Resources Corp.}

In 1981, environmental agencies in New York and New Jersey issued cleanup orders to the Quanta Resources Corporation after discovering that the waste processing company, by mishandling PCBs, had violated the laws of both states. ${ }^{63}$ Recognizing that the cost of bringing its facilities into conformity with state law would far exceed its assets, Quanta filed a voluntary bankruptcy petition under chapter 11 of the Bankruptcy Code. ${ }^{64}$ Fearing that the state environmental agencies might be able to enforce the cleanup orders under the police or regnlatory power exception to the section 362 stay, and unwilling to continue spending over $\$ 1000$ per week to guard the contaminated properties, the Quanta trustee petitioned the bankruptcy court under section 554(a) of the Code for permission to abandon the properties. ${ }^{65}$

Despite objections by the environmental authorities of both states that abandonment would endanger public health and violate state and federal laws, ${ }^{66}$ the bankruptcy court approved the trustee's request. ${ }^{67}$ To reduce the health hazards presented by unattended waste in deteri-

63. Brief for Appellees for the District Court (New Jersey site), at 3, Quanta. The corporation stored more than 500,000 gallons of waste oil, sludge and other refuse-of which some 70,000 gallons were contaminated with hazardous substances-at its Long Island City, N.Y. facility. In Edgewater, N.J., toxicologists discovered that about 400,000 gallons out of some 3.5 to 5 million gallons of oil being stored were contaminated, and that the facility could not be operated safely. Brief for Appellants for the Court of Appeals at 4, In re Quanta Resources Corp., 739 F.2d 927 (3d Cir. 1984), cert. granted sub nom. Midlantic Nat'l Bank v. New Jersey Dep't of Envtl. Protection, 53 U.S.L.W. 3597 (U.S. Feb. 19, 1985) (No. 84-801).

64 . The action was later converted into a liquidation proceeding. Brief for Appellants for the Court of Apeals, supra note 63, at 3.

65. Petition for Certiorari at 5, O'Neill $v$. New York.

66. Quanta, 739 F.2d at 914, 928. The New York and New Jersey authorities argued that abandoning the properties to an irresponsible party-the debtor-constituted unlawful discharge or disposal of hazardous substances. The New York Environmental Conservation Law makes it unlawful to "knowingly dispose of more than fifteen hundred gallons ... of hazardous waste without authorization" from state authorities. N.Y. Envtl. Conserv. Law § 71-2713(7) (McKinney 1984). The New Jersey Spill Compensation and Control Act, N.J. Stat. Ann. $\S 58: 10-23.11$ b(h) (West 1982) prohibits "any intentional or unintentional action or omission resulting in the releasing, spilling, leaking ... of hazardous substance into the waters of the State or onto lands from which it might flow or drain into said waters."

67. In re Quanta Resources, No. 81-05967 (Bankr. D.N.J. filed July 7, 1982 (N.Y. site); May 20, 1983 (N.J. site)). 
orating storage tanks, the New York environmental authorities immediately spent $\$ 2.5$ million on a partial cleanup, and on appeal asked for a first lien against the assets of the estate, or in the alternative, for the reimbursement of their expenses as administrative costs charged to the estate. ${ }^{68}$ The New Jersey environmental agency awaited the results of its appeal of the abandonment order before embarking on a cleanup. ${ }^{69}$

A divided Third Circuit panel reversed the lower court decisions to grant abandonment. ${ }^{70}$ The majority stated that "[i]f trustees in bankruptcy are to be permitted to dispose of hazardous wastes under the cloak of the abandonment power, compliance with environmental protection laws will be transformed into government cleanup by default."71 It rejected the reading given to section 554 by the lower courts and applied a balancing test that weighed the risks to the public against the advantages of abandonment to trustees and creditors. The trustees of Quanta Resources petitioned for certiorari, arguing that the Third Circuit's construction of section 554(a) was inconsistent with the plain meaning and legislative purpose of the statute. ${ }^{72}$

\section{B. The Language and Purpose of Section 554}

The central question in Quanta is one of statutory construction: whether the privilege of abandonment can be qualified through a balancing test where serious public health hazards are present. If the abandonment privilege under section 554 is intended to be absolute, then balancing in light of the public interest would be impermissible.

The language of section 554 is couched in unconditional terms. "After notice and a hearing," the provision states, "the trustee may abandon any property of the estate that is burdensome to the estate or that is of inconsequential value to the estate."73 The statute on its face thus suggests that burdensomeness and worthlessness are sufficient grounds for abandonment, and that no balancing or weighing of additional factors is warranted. Furthermore, nothing in the House or Senate reports of the provision suggests that Congress intended to limit a trustee's statutory authority to abandon if abandonment adversely af-

68. 739 F.2d at 914,929 .

69. Id. at 929 .

70. Id. at 923,929 .

71. Id. at $92 \mathrm{I}$.

72. In re Quanta Resources Corp., 739 F.2d 927 (3d Cir. 1984), cert. granted sub nom. Midlantic Nat'l Bank v. New Jersey Dep't of Envtl. Protection, 53 U.S.L.W. 3597 (U.S. Feb. 19, 1985) (No. 84-801) and case consolidated with In re Quanta Resources Corp., sub nom. O'Neill v. New York, 53 U.S.L.W. 3597 (U.S. Feb. 19, 1985). In addition to the propriety of disallowing abandonment, the trustee challenged New York's request for a first lien on the assets of Quanta Resources. See Petition for Certiorari at 23, O'Neill v. New York.

73. 11 U.S.C. $\$ 554$ (a) (1982). Section 554(b) permits the court, "[o]n request of a party in interest," to order the trustee to abandon property that meets the conditions set forth in part (a). 11 U.S.C. $\$ 554(b)$ (1982). 
fects state police or regulatory powers. ${ }^{74}$ More specifically, it is apparent that Congress did not anticipate the conflict between section 554 and both state and federal environmental laws.

The Third Circuit, in support of its contention that section 554(a) is subject to balancing when the public interest is jeopardized, offered three arguments. First, the court maintained that in the absence of a clear congressional intent to displace state environmental laws, the Bankruptcy Code should not be construed to preempt them. ${ }^{75}$ Since the drafters of section 554(a) did not address its conflict with environmental laws but elsewhere elevated environmental protection objectives over bankruptcy policies, ${ }^{76}$ the court concluded that reading a qualification into section 554 is consistent with the objectives of the Code. ${ }^{77}$

Second, the court relied on 28 U.S.C. $\S 959(b)^{78}$ as statutory support for applying a balancing test to section $554 . .^{79}$ Section 959 (b) requires trustees, receivers, or debtors in possession to "manage and operate" properties of the estate according to the requirements of the "valid laws of the State in which such property is situated." 80 Although section 959(b) had only been applied in a chapter 11 context, ${ }^{81}$ the Quanta court applied it to a chapter 7 proceeding, and argued that the trustee's attempt to abandon contaminated property in violation of state law constituted a violation of section $959(\mathrm{~b}) .{ }^{82}$ Since section

74. The legislative history is brief and unhelpful. See, e.g., H.R. Rep. No. 595, 95th Cong., 1st Sess. 377, reprinted in 1978 U.S. Code Cong. \& Ad. News 5963, 6333; S. Rep. No. 989, 95th Cong., 2d Sess. 92, reprinted in 1978 U.S. Code Cong. \& Ad. News 5787, 5878; 124 Cong. Rec. H11,098 (Sept. 28, 1978).

75. The court expressed the view that where the public interest is involved, the test for preemption (which would preclude balancing) is severe: "[W]here important state law or general equitable principles protect some public interest, they should not be overridden by federal legislation unless they are inconsistent with explicit congressional intent such that the supremacy clause mandates their suppression by the abandonment power." $739 \mathrm{~F} .2 \mathrm{~d}$ at 918.

76. The court referred to $\S 362$ (b)(4), an exception to the automatic stay. Id. The Senate Report specifically included environmental regulatory functions in a list of government actions not subject to $\S 362$ (a). See S. Rep. No. 989, supra note 27, at 52.

77. 739 F.2d at 916-19.

78. 28 U.S.C. $\$ 959$ (b) (1982).

79. 739 F.2d at $919-21$.

80 . The section requires that "[a] trustee, receiver, or manager . . . manage and operate the property in his possession . . . in the same manner that the owner or possessor thereof would be bound to do if in possession thereof."

81. Section 959(b) has been applied to receivers. See, e.g., Gillis v. California, 293 U.S. 62 (1934) (bankruptcy court powerless to authorize receiver's noncompliance with state licensing statute regardless of consequences for the business); Missouri v. United States Bankruptcy Court, 647 F.2d 768, 777-78 (8th Cir. 1981) (trustee in reorganization selling off grain was required to adhere to local licensing regulations), cert. denied, 454 U.S. 1162 (1982). Neither independent research nor the appellants in Quanta could find any instance in which $\S 959(\mathrm{~b})$ has been applied in the chapter 7 context.

82. 739 F.2d at 920 . The argument requires interpreting the filing of the petition to abandon as an act of discharge or disposal under state law, see supra note 66 , as well 
959(b) evidences an intent to accommodate state laws, the Quanta court argued, the court may exercise its traditional equity power to deny the trustee's application for abandonment. ${ }^{83}$

Third, the court maintained that section 554 was meant to codify prior case law. ${ }^{84}$ Citing three early cases that balanced the public interest against a common law abandonment privilege, ${ }^{85}$ the court concluded that a public interest qualification should be read into section 554 , since the framers of the Code did not explicitly disavow such an exception. ${ }^{86}$

None of the justifications for balancing advanced by the Third Circuit, however, is convincing. That Congress specifically excepted some environmental injunctions ${ }^{87}$ from the automatic stay provision ${ }^{88}$ is no indication that the legislature intended policies underlying other provisions of the Code to yield to conflicting environmental protection objectives. The omission of a police power exception for abandonment may have been intentional. ${ }^{89}$ Nor is the court's reliance on 28 U.S.C.

as interpreting disposal as "operation" or "management" under § 959(b). Under this analysis, the trustee might be criminally liable as well. New York City and New York State argued in Quanta that by abandoning without permission from the state, the trustee technically committed a felony under New York State Envtl. Conserv. Law §§ 712713(7) and 71-2721 (McKinney 1984), which make it a crime to "knowingly dispose" of hazardous waste without authorization from state authorities. See Brief for Appellants at 9, In re Quanta Resources Corp., 739 F.2d 912 (3d Cir. 1984), cert. granted sub nom. O’Neill v. New York, 53 U.S.L.W. 3897 (U.S. Feb. 19, 1985) (No. 84-805).

83. 739 F.2d at 920 .

84. 1d. at 916 .

85. Id. at 916-18. For a discussion of two of these cases, see infra text accompanying notes 108-91. The court also referred to In re Chicago Rapid Transit Co., 129 F.2d 1 (7th Cir.), cert. denied, 317 U.S. 683 (1942), see infra note 89.

86. 739 F.2d at 918 .

87. The (b)(4) and (b)(5) exceptions were intended to allow normal police functions to go forward, and provide no general indication that federal bankruptcy policies should yield to environmental concerns. During the debates on the (b)(4) and (b)(5) exceptions to the stay legislative leaders stated that " $[t]$ his section is intended to be given a narrow construction in order to permit governmental units to pursue actions to protect the public health and safety and not to apply to actions by a governmental unit to protect a pecuniary interest in property of the debtor or property of the estate." 124 Cong. Rec. H11,092 (1978) (remarks of Rep. Edwards, Chairman of the Subcommittee on Civil and Constitutional Rights of the House Committee on the Judiciary), reprinted in 1978 U.S. Code Cong. \& Ad. News 6436, 6444-45; see also 124 Cong. Rec. S17,409 (1978) (identical remarks of Sen. DeConcini, Chairman of the Subcommittee of the Judicial Machinery of the Senate Judiciary Committee), reprinted in 1978 U.S. Code Cong. \& Ad. News 6513.

88. 11 U.S.C. \& 362 (1982).

89. Congress could have drafted a qualified abandonment provision had it so intended. For instance, the Bankruptcy Code contains a special provision that the abandonment of railroad lines be consistent with the public interest. 11 U.S.C. $\$ 1170$ (1982). See, e.g., In re Chicago Rapid Transit Co., 129 F.2d 1 (7th Cir.) (trustee for elevated train line ordered to comply with utility abandonment regulations prescribed by state law), cert. denied, 317 U.S. 683 (1942). Because of the special role played by the Interstate Commerce Commission in the industry, however, the railroad provisions 
$\S 959$ (b) persuasive, since section 959(b) has not been applied to liquidation proceedings previously. ${ }^{90}$ Even if section $959(\mathrm{~b})$ directly conflicts with section 554, section 959 is intended to regulate the conduct of court officers, and thus arguably should yield to section 554, a provision in title 11 , the substantive statute. ${ }^{91}$ Moreover, it is doubtful that abandonment by the trustee is equivalent to "operation" or "management" of the waste site. Contrary to the Court of Appeals' analysis, it would "strain the language to construe 'management of the property" " as including the filing of a petition to abandon. ${ }^{92}$

It is also questionable whether courts of appeals possess the equitable power to modify section 554 to accommodate 28 U.S.C. $\$ 959$ (b). Section 105 of title 11 grants the bankruptcy court equitable power "necessary or appropriate to carry out the provisions of this title." The bankruptcy court is not empowered by this section to rely on equity to carry out other statutory provisions. It is certainly not empowered to act contrary to substantive provisions within title 11.93

Finally, the argument that section 554 was intended to codify prior case law is not supported by any statement in the legislative history of the 1978 provision. ${ }^{94}$ Even if codification were intended, it is not evident that Congress chose to incorporate common law exceptions to the traditional practice of unqualified abandonment. ${ }^{95}$ Indeed, until 1973,

are unique. See 5 Collier on Bankruptcy $\uparrow 1170.01$ (15th ed. 1984); see also NLRB v. Bildisco \& Bildisco, 104 S. Ct. 1188, 1195 (1984) ("Obviously, Congress knew how to draft [exceptions] . . . when it wanted to . . . .").

90. See supra notes 80-81 and accompanying text.

91. Title 28 of the Code is designated "Judiciary and Judicial Procedure." Section 959 is within the chapter "General Provisions Applicable to Court Officers and Employees."

92. Quanta, 739 F.2d at 919.

93. See ln re Dunckle Assocs., 19 Bankr. 481, 485 (Bankr. E.D. Pa. 1982) (Section 105 of title 11 "should be exercised only where it is necessary or appropriate to implement provisions of the Bankruptcy Code or where equity and substantial justice requires," not where benefit accrues solely to the creditor.) (footnote omitted).

94. A note to $\$ 4-611$ of the 1973 proposed Bankrupcty Act, however, referred to the common law concept of abandonment. Communication from the Executive Director, Commission on the Bankruptcy Laws of the United States, transmitting a Report of the Commission on the Bankruptcy Laws of the United States, July 1973, H.R. Doc. No. 137, Part II, 93d Cong., 1st Sess. 181, reprinted in A. Resnick \& E. Wypyski, 2 Bankruptcy Reform Act of 1978: A Legislative History, Doc. No. 22 (1979) ("The concept of abandonment is well recognized in case law . . . .").

95. The power to abandon was contemplated by the 1898 Bankruptcy Act with respect to the abandonment of property burdened by taxes, pending applications for patents, trademarks, copyrights, and executory leases. Bankruptcy courts extended the abandonment power to other areas until it was generally acknowledged that in bankruptcy proceedings any type of burdensome property could be abandoned without the need for any special approval by the court. 4 Collier on Bankruptcy, supra note 89, If 554.01 .

However, the 1967 edition of Collier stated that abandonment might be subjected to "general regulations of a police nature." $4 \mathrm{~A}$ Collier on Bankruptcy $\uparrow 70.42(2)$, at 504 (14th ed. 1967) (footnote omitted); see also 9 Am. Jur. 2d Bankruptcy $\$ 257$ (1980) ("'In 
burdensome property could be abandoned without the need for any special approval by the court. ${ }^{96}$

Although bankruptcy abuse by industrial polluters merits judicial attention, the Court of Appeals in In re Quanta Resources overstepped its authority when it read qualifications into section 554(a). Section 554(a) is among the few provisions in the Bankruptcy Code that do not contain explicit exceptions. Forcing a trustee to retain and administer valueless properties could impair his ability to preserve assets for swift distribution to creditors-the paramount purpose of the federal bankruptcy laws. ${ }^{97}$ The Supremacy Clause ${ }^{98}$ mandates that any conflict between the Bankruptcy Code and state environmental laws be resolved in favor of the federal scheme. ${ }^{99}$

The Supreme Court appears to favor the interpretation of abandonment as an absolute privilege. In Kovacs $I I$, the Court observed that the trustee could have sold the contaminated property, or if the costs of bringing it into compliance with state law were greater than its value, the trustee "would likely abandon it to its prior owner, who would have to comply with the state environmental law to the extent of his or its ability." 100 The Supreme Court seems to have adopted an unqualified view of section 554(a), and left any modification up to Congress.

\section{Proposals}

The inability of courts to prevent polluters from abandoning burdensome properties without contravening the clear language of section 554 may seriously undermine the enforcement of laws desigued to protect the environment and the public from hazardous substances.

In enacting sections 554 and 362 , it is unlikely that Congress intended to shield industrial polluters from cleanup obligations. Recent environmental legislation plainly indicates that Congress intends to hold violators of federal law responsible for the consequences flowing

certain situations, the burdens of governmentally imposed obligations . . . may be a significant part of the "burden" which the trustee is seeking to remove . . . .").

96. Bankruptcy Rule 608, superceded by 11 U.S.C. $\S 6007$ (Supp. 1984), provided that the court could "on application or on its own initiative and after hearing on such notice as it may direct, approve abandonment of any property and, without reopening the case may direct the abandonment of any property of inconsequential value discovered after a case is closed." The Advisory Note accompanying the rule indicates its chief purpose was to promote administrative efficiency. See 4 Collier on Bankruptcy, If 554.01, supra note 95. 11 U.S.C.A. 6007 (1984), Rule 6007, effective in 1983, establishes notice, filing, and hearing rules for abandonment.

97. 4 Collier on Bankruptcy, supra note 89 , If 554.01 .

98. U.S. Const. art. V1, cl. 2.

99. Implicit preemption occurs where " " $[t]$ he scheme of federal regulation [is] . . . so pervasive as to make reasonable the inference that Congress left no room for the States to supplement it." " Fidelity Fed. Sav. \& Loan Ass'n v. de la Cuesta, 458 U.S. 141, 153 (1982) (quoting Rice v. Santa Fe Elevator Corp., 331 U.S. 218, 230 (1947)).

100. 105 S. Ct. 705, 711 n.12. 
from their conduct. The Comprehensive Environmental Response, Compensation and Liability Act of 1980101 (CERCLA or "Superfund"), for instance, holds owners, operators, transporters, and other parties responsible for the discharge of waste liable for "all costs of removal or remedial action incurred by the United States Government or a State ... [and] any other necessary costs of response incurred by any other person."102 The Resource Conservation and Recovery Act of 1976 (RCRA) ${ }^{103}$ imposes liability on any person whose handling of hazardous waste endangers the environment. ${ }^{104}$

Abuse of the Bankruptcy Code by industrial polluters not only thwarts federal and state policies, but threatens the public welfare. A legislative solution is the proper response. Although the federal bankruptcy law is not the proper vehicle for direct implementation of environmental protection objectives, Congress has been willing to amend the Code to eliminate abuse and accommodate public interests. ${ }^{105}$

\section{A. Qualification of Abandonment: An Amendment to Section 554}

Congress should amend section 554(a) to permit courts to balance the trustee's interest in preserving the assets of the estate against the state's interest in protecting the public from the dangers of toxic waste abandonment.

101. 42 U.S.C. $\S \S 9601-9657$ (1982).

102. Id. $\$ 9607$ (a)(A) \& (B). A basic goal of CERCLA was "assuring that those responsible for any damage, environmental harm, or injury from chemical poisons bear the costs of their actions." S. Rep. No. 848, 96th Cong., 2d Sess. 13 (1980).

103. 42 U.S.C.A. $\$ \S 6901-6987$ (1983 \& Supp. 1985), Pub. L. No. 94-580, 90 Stat. 2796 (codified as amended at 42 U.S.C.A. $\$ \S 6901-6987$ (1983 \& Supp. 1985). RCRA is an amendment to the Solid Waste Disposal Act of 1965, see Pub. L. No. 91-512, 84 Stat. 1288 (1970).

104. 42 U.S.C.A. § 6973 (1983 \& 1985). The Clean Water Act, Pub. L. No. $91-224$, 84 Stat. 91 (1970) (codified as amended at 33 U.S.C. \$§ 1251-1376 (1982)), also subjects owners and operators of vessels that discharge oil to penalties, regardless of fault. See Note, Strict Liability Under Section 311 of the Clean Water Act: Cleaning Up Respondeat Superior and Negligence, 10 Colum. J. Envtl. L. 149, 150 (1985).

105. For instance, in response to the Supreme Court's recent holding in NLRB v. Bildisco \& Bildisco, 104 S. Ct. 1188 (1984), Congress enacted a limited exception to \$ 365(a) for union contracts. In Bildisco, the Court held that after a voluntary bankruptcy petition has been filed, a collective bargaining agreement-an "executory contract" within the meaning of 11 U.S.C. $\$ 365$ (a)-is no longer enforceable. Id. at 1197-1201. The Bildisco decision therefore permitted a company to terminate a union agreement and to continue operating its business as a debtor in possession. Congressional and public dissatisfaction with this result led four months later to the passage of the union contract exception. Bankruptcy Amendments and Federal Judgeship Act of 1984, Pub. L. No. 98-353, § 541 (a), 98 Stat. 353, 390-91 (to be codified at 11 U.S.C. § 1113), in 1984 U.S. Code Cong. \& Ad. News 390. See N.Y. Times, Feb. 23, 1984, at Al, col.3; Congress Approves Bankruptcy Bill with Compromise Labor Law Provision, 11 Pens. Rep. (BNA) 911 (July 9, 1984). 
There are common law precedents for a balancing approach. ${ }^{106}$ In Ottenheimer $v$. Whitaker, ${ }^{107}$ the Fourth Circuit prohibited a trustee in bankruptcy from abandoning several dilapidated barges. Noting that abandonment would violate a federal statute prohibiting the sinking of vessels in navigable channels, the court argued that the trustee's interest must be balanced against the public interest, as well as the injustice of allowing the trustee to abandon a public obligation associated with the barges while retaining other valuable assets. ${ }^{108}$ In In re Lewis Jones, ${ }^{109}$ a Pennsylvania bankruptcy court required three utility companies to seal up underground manholes, vents, and steam pipes before allowing them to be abandoned, because they might endanger public health. ${ }^{110}$ Moreover, outside bankruptcy, courts have often refused to allow the abandonment of a nuisance and, to protect public interests, have held owners liable for cleanup costs. ${ }^{111}$

A qualification on the abandonment provision of the Bankruptcy Code, however, does present some difficulties. Denying the abandonment of polluted property may delay the proceedings, ${ }^{112}$ expose the estate to additional administrative expense, ${ }^{113}$ and subject the estate to environmental injunctions under a Penn Terra rationale.114 If the cleanup completely exhausts the secured assets of the estate, moreover, the secured creditors might argue that the law effected an "erosion" taking of property protected by the fifth amendment. ${ }^{115}$ Additionally,

106. The court in Quanta argued that these exceptions to standard abandonment practice were codified in $\$ 554$. See supra text accompanying notes 84-86.

107. 198 F.2d 289 (4th Cir.), aff'g In re Eastern Transp. Co., 102 F. Supp. 913 (D. Md. 1952).

108. $198 \mathrm{~F} .2 \mathrm{~d}$ at 290 .

109. 1 Bankr. Ct. Dec. (CRR) 277 (Bankr. E.D. Pa. 1974).

110. Id. at 279.

111. For instance, owners who abandon structurally unsafe buildings are routinely charged with demolition costs incurred by municipalities. See, e.g., City of Paterson v. Fargo Realty Inc., 174 N.J. Super. 178, 415 A.2d 1210 (1980); see also Annot. 43 A.L.R. 3d 916 (1972 \& 1984 Supp.) (discussing validity and construction of statutes and ordinances providing for repair or destruction of residential building by public authorities at owner's expense). But see Ozone Holding Corp. v. City of New York, 79 Misc.2d 744, 361 N.Y.S.2d 558 (Sup. Ct. 1974) (nuisance caused by abandoned paint factory did not present an emergency situation which would have justified owner's liability for costs of demolition that were assessed by city).

112. Petition for Certiorari at 18, O'Neill v. New York, cert. granted, 53 U.S.L.W. 3597 (U.S. Feb. 19, 1985) (No. 84-805).

113. Id. at 23.

114. Penn Terra held that an environmental order to backfill a mine was enforceable under the $\$ 362(\mathrm{~b})(5)$ exception to the stay, despite the likely depletion of the estate. See supra note 33 and accompanying text. The goal of $\$ 554(a)$, however, is to allow trustees to reject properties that are burdensome. If an estate must hold onto property and expend funds to clean it up while bankruptcy proceedings are in progress, then this goal is compromised.

115. The amendment declares that private property shall not "be taken for public use, without just compensation." U.S. Const. amend. V. Secured property is subject to the takings clause, see United States v. Security Indust. Bank, 459 U.S. 70, 75 (1982) 
the interest in rehabilitation that reorganization proceedings serve would be jeopardized if an otherwise salvageable company is pushed into liquidation because it is forced to comply with a cleanup order. ${ }^{116}$

These problems, however, are not insurmountable. Some additional delay would result if the proposed change were made, but restricting section 554 balancing only to those properties subject to environmental cleanup orders and debts would minimize the disruptive effect. ${ }^{117}$ Where special administrative hardships ${ }^{118}$ were involved, or the trustee would be exposed to unreasonable personal liability because of disallowance, the court might exercise its equitable power under section $105^{119}$ to provide relief.

Although the Supreme Court in Kovacs $I I^{120}$ expressly declined to decide whether an environmental injunction that could only be satisfied by spending money is equivalent to a money judgment for purposes of section 362(a), 121 a consistent extension of the Court's rationale suggests that any obligation that could not be met personally should be viewed as equivalent to a money payment. ${ }^{122}$ If this is the case, the vulnerability of an estate to injunctions of the Penn Terra type would be limited. ${ }^{123}$

A qualification on the right to abandonment, furthermore, does not in itself effect an "erosion" taking, since disallowing abandonment in a liquidation context does not force a trustee to apply assets subject to an indefeasible security interest to maintain the property. ${ }^{124}$ Even if

("The bankruptcy power is subject to the Fifth Amendment's prohibition against taking private property without compensation.") (dictum).

116. In re Quanta Resources Corp., 739 F.2d 912, 926 (3d Cir. 1984) (Gibbons, J., dissenting), cert. granted sub nom. O'Neill v. New York, 53 U.S.L.W. 3597 (U.S. Feb. 19, 1985) (No. 84-805) and case consolidated with In re Quanta Resources Corp., 739 F.2d 927 (3d Cir. 1984), cert. granted sub nom. Midlantic Nat'l Bank v. New Jersey Dep't of Envtl. Protection, 53 U.S.L.W. 3597 (U.S. Feb. 19, 1985) (No. 84-801).

117. Most litigation over the abandonment privilege concerns whether or not property is burdensome or inconsequential, or whether property was in fact abandoned by acts or omissions of the trustee. See, e.g., Sparhawk v. Yerkes, 142 U.S. 1, 14 (1891) (as assignees in bankruptcy did nothing to assert claim over bankrupt's suspended exchange seat for 10 years, the bankrupt could reclaim seat; the assignees had in effect abandoned the property); In re Brenna, 5 Bankr. 505 (Bankr. V.I. 1980) (automobile not clearly inconsequential). See generally 11 U.S.C.A. annot. \& 554 (1979 \& Supp. 1985) (collecting cases). The proposed change would have little or no impact on these issues.

I18. See supra note 82.

I19. 11 U.S.C. $\$ 105$ (1982).

I20. 105 S. Ct. 705 (1985).

121. Id. at 707 .

I22. See supra text accompanying notes 54-55.

123. The stay would operate until the bankruptcy proceedings had come to a conclusion. See supra notes 18, 29 and accompanying text. Taken as a whole, the proposals advanced in Part III would provide a greater opportunity for environmental authorities to recover cleanup debts through the bankruptcy proceedings and a diminished opportunity for them to do so by excepting to the stay.

124. Even if the court denies abandonment, the estate may still seek protection 
the court's refusal to grant the privilege to abandon a site exposes the estate to cleanup costs that invade secured assets, the court still must determine if the cleanup order is a permissible exercise of the state's regulatory power to protect the public good or whether the environmental statute effects a compensable taking of the secured creditor's property. ${ }^{125}$

Disallowing the abandonment of a waste site might hinder the rehabilitation of a company. 1t is not clear, however, whether the current scheme permits a polluter to abandon toxic waste in a chapter 11 context. ${ }^{126} 28$ U.S.C. $\$ 949$ (b) may prohibit chapter 11 debtors from abandoning hazardous sites in violation of state and local laws. ${ }^{127}$ The Bankruptcy Code, in any event, has not been structured to make reorganization and liquidation equally desirable to corporations considering its protection. The Code already contains provisions that allow assets to be drained from an estate in a way that makes liquidation the only feasible option. ${ }^{128}$ If reorganization becomes an unattractive alternative for some corporations as a result of the proposal, liquidation is still available.

\section{B. Nondischargeability of Cleanup Debts: An Amendment to Section 523(a)}

Restricting abandonment is, however, only a partial solution to the abuse problem. According to Kovacs II, an environmental debt can be

under the $\$ 362$ (a) stay. The trustee in Quanta could have sought protection from the terms of the New York City Charter and Code, \& C19-50 (1976 \& Supp. 1984), which, because it required the maintenance of an operational fire system and round-the-clock supervision of bulk oil storage facilities, compelled the trustee to spend assets to guard the Long Island City facility during the bankruptcy proceedings.

125. A takings problem results if trustees are required to exhaust the secured assets of an estate to comply with cleanup orders. Where there is a permanent physical invasion of property, government appropriation generally is barred, see Pennsylvania Coal Co. v. Mahon, 260 U.S. 393 (1922). But under a "noxious use" theory, government may abate a dangerous threat to health and safety even if abatement reduces the value of the property to zero. See Agins v. City of Tiburon, 447 U.S. 255 (1980) (municipal restrictions on building density not a taking); Penn Cent. Transp. Co. v. City of New York, 438 U.S. 104 (1978) (landmark preservation); Goldblatt v. Town of Hempstead, 369 U.S. 590 (I962) (ordinance prohibiting excavations, effectively destroying business, upheld); Hadacheck v. Sebastian, 239 U.S. 394 (1915) (prohibition of brickmaking validated on nuisance theory). Thus a cleanup order which exhausts secured assets may be permissible.

126. See supra notes $8 \mathrm{I}-83$ and accompanying text.

127. This would depend upon the applicable state or local law. See supra notes 66 , 82 and accompanying text. See generally Hoffman, supra note 14, at 695-98 (§ 959 requires trustee to operate business in compliance with state laws.).

128. Certain debts are not dischargeable in bankruptcy. See 11 U.S.C. $\$ 523(a)(1)$ (taxes), (a)(2) (obtained under false pretenses), (a)(4) (incurred through fraud in a fiduciary capacity, embezzlement, or larceny), (a)(5) (alimony or child support), (a)(6) (incurred through willful and malicious injury to another), (a)(7) (fines owed to governmental units), (a)(8) (goverumentally guaranteed educational loans). 
discharged in a personal bankruptcy proceeding. ${ }^{129}$ Thus, where environmental authorities incur expenses either because cleanup costs exceed available assets, or where, in response to crises, the agencies expend their own funds, a discharge may insulate responsible parties from personal liability for cleanup debts. As one commentator has pointed out, discharging a debt is "to some extent, condoning the behavior [giving rise to the debt]."130 By tolerating the violation of federal and state laws, the discharge granted as a result of Kovacs II diminishes the deterrant effect of environmental enforcement.

While discharge has been considered the "heart of the fresh start provisions of the bankruptcy law,"131 the fresh start policy "is not so important . . . as to negate other important policies which the law feels a responsibility to foster and abet . . . . Certain debts created by the debtor's unlawful or oppressive conduct should remain his obligations." 132 Section 523(a) establishes nine kinds of debts which Congress determined should not be discharged, most of which "concern misconduct by the debtor in the events leading up to the bankruptcy." 133 Among the debts that section 523(a) makes nondischargeable are debts owed for certain taxes; ${ }^{134}$ spousal or child support; ${ }^{135}$ certain kinds of malicious ${ }^{136}$ and fraudulent conduct; ${ }^{137}$ and fines and penalties imposed by governmental units. ${ }^{138}$ The bankruptcy laws cannot be exploited to avoid nondischargeable debts, because these debts follow a debtor until they have been satisfied. ${ }^{139}$

Cleanup debts which polluters seek to discharge are the result of tortious misconduct which is no less antisocial or irresponsible than the behavior leading to the debts made nondischargable by section $523(\mathrm{~b})$. Considering the widespread nature and gravity of the problem of toxic waste, that should not be dischargeable, section 523(a) should therefore be amended to include debts for cleanup obligations.

Even if section 523 is amended to prevent discharge of environmental debts, corporate officers can take shelter from personal liability for irresponsible management through the corporate form. ${ }^{140}$ If envi-

129. See supra text accompanying notes 50-53.

130. D. Cowans, Cowans Bankruptcy Law and Practice 448 (1983).

131. S. Rep. No. 989, 95th Cong., 2d Sess. 98 (1978).

132. D. Cowans, supra note 130 , at 373-74.

133. H.R. Rep. No. 595, 95th Cong., 1st Sess. 128, (1977).

134. 11 U.S.C. $\$ 523(a)(1)$ (1982).

135. Id. $\S 523(\mathrm{a})(5)$.

136. Id. $\S 523(\mathrm{a})(6)$.

137. Id. $\S 523(\mathrm{a})(2),(\mathrm{a})(6)$.

138. Id. $\S 523(\mathrm{a})(7)$.

139. Id. \& 524 .

140. Establishing subsidiary corporations may shield large corporations from major losses in the event of environmental actions. Quanta Resources Corporation is a wholly owned subsidiary of Quanta Holding Corporation, which is a wholly owned subsidiary of A.G. Becker Inc., which is a successor corporation to Warburg Paribas, Becker, Inc. Telephone interview with Richard Engel, Deputy Attorney General of the State of New 
ronmental laws have vicarious liability provisions that make officers responsible for the cleanup debts of their corporations, however, the deterrent force of the proposed amendment to section 523 would be magnified. Federal and state environmental laws already contain vicarious liability provisions which may hold corporate officers liable for cleanup costs under some circumstances. ${ }^{141}$ Both CERCLA ${ }^{142}$ and RCRA, ${ }^{143}$ for example, make it possible to bring suit against any "owner or operator" of a hazardous waste facility who contributes to an activity that "may present an imminent and substantial endangerment to health or the environment."144 State legislatures should, therefore, consider strengthening the vicarious liability provisions of their antipollution laws.

\section{Reimbursement for Cleanup Debts: An Amendment to Section 507}

The EPA has estimated that the cost to the federal government alone of cleaning up the more than 22,000 existing abandoned waste sites is as high as 16 billion dollars. ${ }^{145}$ States will be spending even more. ${ }^{146}$ Still more will be required to pay for cleanup costs which polluters are able, through the current bankruptcy scheme, to shift to taxpayers. ${ }^{147}$

The proposed amendments to sections 554(a) and 532(a) will not significantly improve the chances for reimbursement of cleanup costs within the bankruptcy proceedings. Debts owed to environmental

Jersey (Feb. 8, 1985) (referring to interrogatories of May 1984, In re Quanta Resources, N.J. Office of Admin. Law, docket no. 2334-83); see also State Dep't of Envtl. Protection v. Ventron Corp., 94 N.J. Super. 473, 501, 468 A.2d 150, 165 (1983) (parent corporation not held liable for mercury contamination by subsidiary in Meadowlands creeks). Although fraud provisions enable courts to pierce the corporate veil, they are not tailored to eliminate such abuse. See In re Typhoon lndus., 6 Bankr. 886 (Bankr. E.D.N.Y. 1980) (corporation is entitled to the presumption of separateness); N.Y. Times, Feb. 6 , 1985, at Al, col. 4 ("problem . . . involves a string of seven or eight . . . companies owned in various combinations by three brothers who have been cited scores of times for illegally dumping construction wastes ... ").

141. 42 U.S.C. $\$ 6903(15)$, defines "person" to include individuals. The "imminent hazard" provision, $\$ 6973$, extends liability for response costs to individuals who own or operate or have owned or operated polluted sites, and who are somewhat responsible for the hazard created. See United States v. Price, 523 F. Supp. 1055, 1072-74 (D.N.J. 1981) (indifferent owners of property who bought years after dumping, as well as the previous owners, could be held liable for cleanup), aff'd, 688 F.2d 204 (3d Cir. 1982); see also 42 U.S.C. $\$ 9601(20)(A)$ (1982) (CERCLA extends liability to operators); 33 U.S.C. $\$ 1321$ (1982) (The Clean Water Act holds owners, operators, and "persons in charge" of unlawful discharges liable).

142. 42 U.S.C. $\$ \S 9601-9657$ (1982); see also supra note 141 (liability for individuals).

143. 42 U.S.C. $\$ \S 6903,6973$ (1982); see also supra note 142 (CERCLA).

144. See supra note 141 .

145. N.Y. Times, Feb. 8,1984 , at A18, col. 1 .

146. See id.

147. Hoffman, supra note 14, at 672; N.Y. Times, Mar. 25, 1984, at A48, col. 4. 
agencies stand seventh in priority behind other unsecured claims, according to the terms of section 507. ${ }^{148}$ Given this low priority, chances of substantial repayment are minimal.

To diminish the drain on environmental authorities as a result of unfavorable bankruptcy settlements, section 507 should be amended to include environmental debts within the first priority: expenses incurred to administer a bankrupt estate. ${ }^{149}$ Cleanup costs-charges incurred for preserving and rehabilitating properties of the estate-ought to be considered administrative expenses, and should not be externalized. Ten state legislatures have passed "superlien" laws which would make environmental cleanup debts superior to secured claims. ${ }^{150}$ At the federal level, a proposal to establish a "super-superpriority" for RCRA and Superfund debts-ahead of secured and unsecured claimswas introduced in the House of Representatives, but died in committee. ${ }^{151}$

Opposition to state "superliens" has centered on their adverse impact on secured creditors, ${ }^{152}$ and on their conflict with the priorities of the federal bankruptcy provision. ${ }^{153}$ By placing certain governmental

148. 11 U.S.C. $\$ 507$ (a) (1982 \& Supp. 1984) provides, in pertinent part, the following priorities: first, administrative expenses; second, certain claims arising from timing differences related to the filing of the bankruptcy petition; third, allowed unsecured claims for wages, salaries, and commissions; fourth, allowed unsecured claims for contributions to employee benefit plans; fifth, unsecured claims of individuals less than $\$ 900$; sixth, certain agricultural claims; seventh, claims of governmental units. An environmental agency is a governmental unit.

149. Administrative expenses include "the actual, necessary costs and expenses of preserving the estate." 11 U.S.C. $\$ 503(\mathrm{~b})(1)$ (A) (1982). A first-priority administrative claim can be overridden by a $\S 507$ (b) "superpriority" in cases in which certain secured claims have been underpaid. See 11 U.S.C. $\$ 507$ (b) (1982).

150. The laws vary in their language and effect. In most, the environmental authority has some time after taking a response action in which to perfect a lien against some or all property of a polluter; its claim is then superior to other claims. See, e.g., Massachusetts Oil and Hazardous Material Release Prevention and Response Act, Mass. Ann. Laws ch. 21E, $\S 13$ (Michie/Law. Coop. 1980); New Hampshire Solid and Hazardous Waste Management Act, N.H. Rev. Stat. Ann. \$ 147-B:10 (Supp. 1983); New Jersey Spill Compensation and Control Act, 58 N.J. Stat. Ann. $\S 10-23.11$ (West 1982 \& Supp. 1983). Other states with similar provisions include California, Colorado, Illinois, Maryland, Montana, New York, Ohio, South Dakota, Virginia and Washington.

151. H.R. 2767, 98th Cong. Ist Sess. (I983) (sponsored by Rep. Florio); H.R. 7172 97th Cong., 2d Sess. (1982) (sponsored by Rep. Florio).

152. According to the Wall Street Journal, "[t]he legislation has raised an outcry from builders, bankers and insurers . . . ." Lipman, Unwitting Owners May Owe for Cleanup of Toxic Wastes, Wall St. J., Aug. 1, 1984, at 27, col. 1. Before granting loans or issuing title insurance, many Massachusetts banks now require site assessments at up to $\$ 15,000$ each to certify freedom from contamination. The Federal Home Loan Mortgage Corporation withdrew from the mortgage market in the state as a result. Efforts to repeal superliens have been made in California, Massachusetts and New Jersey. Id.; see also Schwenke \& Lockett, Superlien "Solutions" to Hazardous Waste, ABA Envtl. L. Newsletter, Winter I983-4, at 1, 1-10.

153. Schwenke \& Lockett, supra note 152 , at 4 . 
units ahead of even secured creditors, they intrude on classificationssuch as section 507-that have been established by the Federal Bankruptcy Reform Act. ${ }^{154}$ The federal "super-superpriority," it is objected, would require the repayment of environmental debts ahead of all claims, and would thus have a crushing economic impact on the affected industries. ${ }^{155}$

Giving environmental liens a first level priority under section 507 avoids these problems. To elevate them to the first class of claims improves their chances for satisfaction; yet by ranking environmental debts behind those of secured creditors, the impact on the financial viability of companies that handle toxic substances is minimized. This reordering may result in lower recovery for lenders and higher borrowing rates for entire industries that handle toxic substances. But lesser recoveries and higher rates are reasonable burdens for parties to assume if they deal with companies that handle toxic substances. ${ }^{156}$

A remaining question is whether the problems discussed could be alleviated by imposing stringent financial responsibility requirements on potential polluters to pay for cleanup costs in the event of bankruptcy. Both commentators and legislators have sought to rely on costspreading measures to solve the problem; federal and state environmental laws, furthermore, include a variety of special insurance, bonding, tax, or other "financial responsibility" requirements. ${ }^{157}$ The feasibility of having industry pay for the entire cost of cleaning up toxic

154. Justice O'Connor, in her concurrence in Kovacs $I I$, suggested that environmental preference legislation by the state might be an appropriate way to improve the priorities for state environmental cleanup debts. $105 \mathrm{~S}$. Ct. 705, 712 (1985). Yet the opposing concern is that states will through their own laws devise preferences among creditors that the federal bankruptcy law does not recognize. See In re Universal Money Order Co., 470 F. Supp. 869 (S.D.N.Y. 1977) (California banking order invalidated because it singled out one class of creditors at the expense of others).

155. Schwenke \& Lockett, supra note I52, at 4 .

156. The Senate Report on the Superfund legislation (CERCLA) stated the view that " $[t] \circ o$ often the general taxpayer is asked to pick up the bill for problems he did not create; when costs can be more appropriately allocated to specific economic sectors and consumers, such costs should not be added to the public debt." S. Rep. No. 848, 96th Cong., 2d Sess. 23 (1980). The environmental authorities in Quanta argued that

If [creditors have been] dealing with a company which was flaunting [sic] the hazardous waste laws, their recovery [in bankruptcy] may have to be . . . limited . . . in order that the health and safety of the public can be protected. . . . It is the public at large, whose safety is endangered, that is the truly innocent victim.

Brief for Appellants at 25-26, In re Quanta Resources Corp., 739 F.2d 912 (3d Cir. 1984), cert. granted sub nom. O’Neill v. New York, 53 U.S.L.W. 3597 (U.S. Feb. 19, 1985) (No. 84-805).

157. Superfund and RCRA, for example, contain provisions which grant the EPA authority to require "evidence of financial responsibility." 42 U.S.C. $\$ 9608$ (1982); 42 U.S.C. § 6924 (Supp. 1985); see also Schmalz, Superfunds and Tort Law Reforms-Are They Insurable?, 38 Bus. Law. 175 (1982) (private insurance possibilities under CERCLA and similar legislation). 
waste sites, however, is questionable. ${ }^{158}$ Any general statutory requirement, tax, or bond that is imposed on an industry-wide basis is not related to the particular disposal practices of an individual firm, and consequently cannot deter the improper handling of waste. According to Dean Calabresi, the best deterrence of improper disposal requires that costs be borne by each firm in accordance with the volume of waste it generates. ${ }^{159}$ Professor Epstein has also argued that insurance only transfers and pools risks. Insurance "cannot reduce the costs associated with those risks or the uncertainties involved in their measurement." 160 Cost-spreading approaches may provide a method of paying for cleanups and consequently reduce the need for polluters to take advantage of bankruptcy laws, but they are unlikely to have a deterrent effect on misconduct within the industry. ${ }^{161}$

Without disturbing the protective function of the stay provision for debtors, or thwarting the legitimate purposes of abandonment, the amendment of section 507, section 523(a), and section 554(a) will enhance the deterrent effect that Congress intended to produce by passing environmental legislation. It will curb abuse of the bankruptcy law by polluters, and will increase the amounts that can be recovered from them.

\section{ConClusion}

The recent decision of the Third Circuit in In re Quanta Resources qualified section 554 of the Bankruptcy Code by refusing to allow a trustee in bankruptcy to abandon a dangerous toxic waste site. Although the public interest in denying abandonment was compelling, the history and language of the abandonment statute do not allow this result. This problem is part of a larger clash between the Bankruptcy Code and the environmental legislation of the states and the federal government.

The decision of the Supreme Court in Kovacs $I I$, which considered aspects of the conflict between the Code and environmental laws, did

158. Schmalz, supra note 157. The legislative history of the recent amendments to RCRA, supra note 103, acknowledges that the impact of tighter regulations, including more stringent financial responsibility requirements, will be "a tough burden," and that insurers will be liable for the amount of coverage provided; this will not necessarily include the total cost of cleaning up. H.R. Rep. No. 198, Part I, 98th Cong., 2d Sess. 37-38, reprinted in 1984 U.S. Code Cong. \& Ad. News 5576, 5596-97; H.R. Rep. No. I133, 98th Cong., 2d Sess. 91, reprinted in 1984 U.S. Code Cong. \& Ad. News 5649, 5662. Recently, furthermore, the pollution-liability insurance field "has virtually collapsed." Walsh, Insurers Are Shunning Coverage of Chemical and Other Pollution, Wall St. J., Mar. 19, 1985, at 1, col. 6.

159. G. Calabresi, The Costs of Accidents 144-47 (1970).

160. R. Epstein, Modern Products Liability Law 48 (1980) (discussing product liability insurance).

161. Note, Allocating the Costs of Hazardous Waste Disposal, 94 Harv. L. Rev. 584, 597-98 \& n.63 (1981). 
not resolve crucial issues or provide needed guidance. To curb abuse of the bankruptcy laws without impairing the automatic stay provision, the Code should be amended to qualify the abandonment privilege and to prevent the discharge of cleanup orders in personal bankruptcy. States should consider adding stronger vicarious liability provisions to existing environmental laws. Finally, to improve opportunities for environmental authorities to recover cleanup debts, these debts should be given higher priority within the bankruptcy scheme.

Norman I. Silber 